University of Nebraska - Lincoln

DigitalCommons@University of Nebraska - Lincoln

Faculty Publications: Department of Entomology

Entomology, Department of

2002

Registration of N547 Maize Germplasm Line

Nora E. D'Croz-Mason

University of Nebraska-Lincoln, ndcroz-mason2@unl.edu

John E. Foster

University of Nebraska-Lincoln, john.foster@unl.edu

Stephen C. Mason

University of Nebraska-Lincoln, smason1@unl.edu

Follow this and additional works at: https://digitalcommons.unl.edu/entomologyfacpub

Part of the Agriculture Commons, Entomology Commons, and the Genetics and Genomics Commons

D'Croz-Mason, Nora E.; Foster, John E.; and Mason, Stephen C., "Registration of N547 Maize Germplasm Line" (2002). Faculty Publications: Department of Entomology. 538.

https://digitalcommons.unl.edu/entomologyfacpub/538

This Article is brought to you for free and open access by the Entomology, Department of at DigitalCommons@University of Nebraska - Lincoln. It has been accepted for inclusion in Faculty Publications: Department of Entomology by an authorized administrator of DigitalCommons@University of Nebraska - Lincoln. 
Published in Crop Science 42:1 (2002), p. 312. doi:10.2135/cropsci2002.3120

Copyright (c) 2002. Crop Science Society of America. Used by permission.

\title{
Registration of N547 Maize Germplasm Line
}

\author{
N. E. D'Croz-Mason, ${ }^{1}$ J. E. Foster, ${ }^{2}$ and S. C. Mason ${ }^{1}$ \\ 1 Department of Agronomy, University of Nebraska, Lincoln, NE 68583-0915 \\ 2 Department of Entomology, University of Nebraska, Lincoln, NE 68583-0915 \\ Corresponding author-ndcroz-mason2@unl.edu
}

N547 germplasm line (Reg. no. GP-367, PI 615526) was released by the Agriculture Research Division, Institute of Agriculture and Natural Resources, University of Nebraska, on 24 Aug. 1999. N547 is a yellow endosperm maize inbred germplasm with resistance to stalk and shank tunneling damage caused by the second generation of the European corn borer (ECB) Ostrinia nubilalis (Hubner).

N547 was derived by selfing a selected full-sib family from MBITA, a tropical population developed by CIMMYT, Mexico. MBITA was created to recombine sources of resistance to temperate and subtropical stalk borers. These insects included $E C B$, southwestern corn borer (SWCB) Diatraea grandiosella (Dyer), sugarcane borer (SCB) D. sacharallis (F.), spotted stem borer Chilo partellus Swinhoe, pink stem borer Sesamia calamistis Hampson, sugarcane borer (African) Eldana saccharina Walker, and African maize stalk borer Busseola fusca (Fuller) (Smith et al., 1989).

The germplasm line was advanced ear-to-row by self-pollination to $S_{5}$ with selection primarily on the basis of resistance to second generation ECB damage, earliness, low plant and ear height, resistance to stalk and root lodging, and resistance to stalk and shank rot.

During the $S_{1}, S_{3}$, and $S_{5}$ generations, five to six plants per family were manually infested with ECB larvae. European corn borer resistance was determined by infesting plants with 50 neonate larvae at the ear node, and at the nodes immediately above, and immediately below the ear. The $S_{5}$ generation was infested twice at the ear node only. $S_{2}$ and $S_{4}$ generations were not infested. Stalk and shank injuries were determined by splitting both and counting, the number of tunnels (cavities) per plant. Only plants with no tunneling in either the stalk or the shank (a 0,0 score) were advanced to the next generation. The susceptible check, Mo17, averaged a score of 5 tunnels in the stalk and 1 tunnel in the shank $(5,1)$.

Although N547 contains tropical germplasm, it is adapted to Nebraska. N547 has uniform, open, yellow-reddish tassels, is a good pollen shedder, and it requires $72 \mathrm{~d}$ from planting to pollen shedding at Lincoln, NE. Silks are yellow-reddish and their emergence begins two to three days after pollen shed begins. N547 produces uniform and sturdy plants with an average plant height of $1.90 \mathrm{~m}$ and ear height of $0.78 \mathrm{~m}$. Ears are conical 
shaped, 0.15 to $0.17 \mathrm{~m}$ long, and have 12 to 14 kernel rows with relatively small yellow kernels on a white cob. N547 has not been evaluated for disease nor other insect resistance.

N547 is being released for use as germplasm for line development based primarily on its native resistance to $E C B$. Selfed progeny from the selected $S_{5}$ plants were sibbed to increase seed. Seed is currently maintained by sibbing and bulking. Breeder seed is available from the Department of Agronomy, University of Nebraska, Lincoln, NE 685830915. Seed is available free to public sector researchers and for a fee of $\$ 50.00$ per 35kernel sample to private sector researchers. Recipients of the seed should make appropriate recognition of the source of the germplasm if it is used to develop a new germplasm, parental line, or hybrid.

\section{References}

Smith, M.E., J.A. Mihm, and D.C. Jewell. 1989. Breeding for multiple resistance to temperate, subtropical, and tropical maize insect pests at CIMMYT. p. 222-234. In Toward insect resistant maize for the Third World: Proc. Int. Symp. Methodologies for Developing Host Plant Resistance to Maize Insects. CIMMYT, Mexico D.F.

Published as paper No. 13172, Journal Series Nebraska Agric. Res. Div. 